Article

\title{
'Go and Prophesy in Your Own Land': Foreign Prophets and Popularism in South Africa. Evoking the Need of Jonathanic Theology for Peaceful Resolution of Difference
}

\section{Bekithemba Dube}

Education, University of the Free State, QwaQwa 9866, South Africa; bekithembadube13@gmail.com

Received: 14 November 2019; Accepted: 13 December 2019; Published: 13 January 2020

\begin{abstract}
Informed by a decoloniality lens and referencing motifs such as coloniality of power, knowledge, and being, this theoretical article analyses and problematises conflict, and reconstructs the experience of foreign and local prophets in South Africa. There is growing tension between foreign pastors and local pastors, with the former seemingly being popular because of performing 'miracles,' huge followings, and, in some cases, through mafia tendencies, which ignite the notion that expelling them from South Africa can be a counter-hegemony strategy to deal with popularism and criminality. The articles respond to two questions in this article: What factors influence conflict between migrant and local prophets? and, how can the story of David and Jonathan be used as a starting point for collective engagement in a process to achieve peace and healing? The article ends with arguing that the Jonathanic theology of peace, if pursued by migrant and local prophetic movements in South Africa, can reconstruct the prophetic terrain and assist in facilitating a rehumanising process, in addition to enacting the ontological density that has been lost. The article ends by arguing that Jonathanic theology is doable and desirable as a sustainable solution for religious conflict in South Africa.
\end{abstract}

Keywords: Jonathanic theology; migrant prophets; legislation; peace and decoloniality

\section{Introduction}

The prophetic terrain in the South African space has entered exciting, yet disturbing, times (Dube et al. 2017). It is interesting, because innovations are emerging in the prophetic space, which we, or, at least, people with an orthodox or conventional theological orientation, would not have imagined. It is disturbing, because prophetic movements have evoked wars through their prophets, based on nationality, popularity, and, in some cases, jealousy. The tension between local and foreign prophets is described best by Vorster (2017), who says the tension is between 'us,' clothed in a cloud of uniqueness, and 'them,' clothed in a cloud of otherness. Demarcation is followed by idolising the 'us' and demonising the 'them.' This article refers to various research studies that have been conducted on prophetic movements in South Africa.

My article is placed against the background provided by various studies that have been conducted on contemporary prophets in South Africa. However, no study has focused on the conflict between local and foreign prophets. An important study was done by Magezi and Banda (2017), who argue that the rise of Christian ministerial practices that emphasise wealth and prosperity ultimately raises questions about the appropriateness of using church ministry and theological education as instruments for economic survival. They note, furthermore, that Africa continues to see an increase in wealthy church pastors and prophets who preach the gospel of material prosperity. They conclude their research by arguing that there is a need to instill an ecclesiology that decommodifies the church and instills within Christian ministers the idea that, even though they can expect to survive financially through 
their churches, they must be accountable to the churches they lead. Kgatle (2018) conducted a study on contemporary prophets in South Africa, and argues that the prophetic voice addresses injustices in society. While this may be true, to an extent, the prophetic voice as demonstrated by some ministries is cause for concern, due to their mafia tendencies and their disregard for social justice-an example is Seven Angels Ministry (Dube 2019). Mafia tendencies as used in this article refer to criminality elements hidden within or in religious praxis and discourses that undermine the beauty of religion in society. Various examples of mafia tendencies will be referred to in this article as it unfolds, since it is one of the reasons for the conflict between local and foreign prophets in South Africa (Evans 2019; Collinson 2017; The Commission for the Promotion and Protection of the Rights of Cultural, Religious and Linguistic Communities Right (CRL Rights Commission 2017); Montsho 2019; Matangira 2019; Lindeque 2019; TimesLIVE 2019).

Another study was conducted by Pondani (2019), who argues that there has been an increase in prophets who apply dangerous so-called healing practices, such as eating snakes, drinking petrol, and the popular spraying of Doom (an aerosol insecticide), which endangers the lives of congregants who are desperate for that special miraculous touch. He concludes by arguing that there is a pressing need for religious communities, governments, and organisations to guard against abusive tendencies disguised as healing, and power.

After considering recent research in this area, there is realisation that none of the article focus is on the conflict between local and foreign prophets, or had a thrust to tease and unmute discourses in South Africa, and evoke the need for prophets to be agents of change and peace. Thus, the article is unique, because of its approach to the conflict between local and foreign prophets, which originates from the three decoloniality motifs of coloniality of power, knowledge, and being. My aim is to reinvent a new prophetic order and ways of thinking-to think anew, beyond modernity and the neoliberal approach to faith praxis in South Africa. It is also unique in that it problematises practices deemed to be a source of conflict and, finally, suggests how various tenets of the Jonathanic theology can promote coexistence and peace among the various prophetic movements in South Africa.

\section{Elaboration of the Problem}

Conflict is not limited to the prophets, but has escalated to include the media, judiciary system, politicians, and the general populace. The attitudes of citizens toward foreign prophets are clear from a petition with almost 5900 signatories quoted by Sain (2018): “As the citizens of South Africa we stand together in one voice requesting our government to please close down all these foreign prophetic churches based in South Africa with immediate effect to avoid more victimisation of our citizens, whether sexually, financially, emotionally or otherwise, in the name of miracles. We request that our government regulate our churches, and monitor and evaluate their activities."

The reasons given for demanding that foreign prophetic churches are closed down is based on a rather simplistic understanding of the problems related to religion in postcolonial states. This is because even some local prophetic movements are involved in problematic practices, as Sain (2018) explains, practices which, naturally, also pose a threat to humanity. For example, the Seven Angels Ministry is a local ministry that has been involved in armed robbery, constitutional delinquency, and financial misappropriation (Dube 2019). Prophet Mnguni of End Times Disciples Ministries in Soshanguve, Pretoria, is well known for his act of feeding his followers snakes-which, he claims, turns into chocolate (Makhudu 2018). Furthermore, Prophet Light Monyeki of Grace Living Hope Ministries, also in Soshanguve, claims to have received a shocking revelation from Prophet Monyeki: drinking rat poison mixed with water is an act of "the power of God" (Makhudu 2018). The list of examples of both local and foreign prophets who have been caught on the wrong side of the law is endless. Nevertheless, the foreign prophets are victims of partial democracy—though the article does not say their acts of criminality are justified. My point is that crimes relating to prophetic acts are not limited to nationality, or race, but that all humanity is susceptible to crime, and that justice must be served to all, and not selectively. 
Close consideration of the conflict between local and foreign prophets described above led me to realise that the prophetic movement in South Africa is marred by violence (Ndabeni 2017; Evans 2018; Sun Reporter 2019). However, as noted by Sithole (2014, p. viii), this violence is not visible, but is hidden, and those who are affected by it seem to be incapacitated and unable to see, name, describe, or explain it. The violence is institutionalised, naturalised, and normalised in everyday existence. Therefore, Ndlovu-Gatsheni (2013a) warns Africans by saying, "What Africans must be vigilant against is the trap of ending up normalizing and universalizing coloniality as a natural state of the world. It must be unmasked, resisted and destroyed because it produced a world order that can only be sustained through a combination of violence, deceit, hypocrisy and lies."

In light of this tension between local prophets, citizens, and politicians, on the one hand, and foreign prophets, on the other, there is need for religious leaders who support social justice to be harbingers of peace and, to achieve peace, their narratives and praxis should entail and foster the feasibility of coexistence and peaceful resolution of differences. To achieve this goal, the article, that a rereading, in a decoloniality sense, of the story of David and Jonathan in the context of conflict can serve as terrain that can be pursued to mitigate trajectories and ambivalence between and among local and foreign prophets in South Africa, could contribute to the construction of sustainable peace. While the task may appear difficult, especially in the context of conflict, it is doable, desirable, and inevitable. Sithole (2014) is of the view that there is a need to keep on thinking, even to the point of exhaustion, to avoid coloniality of mind, conflict and dehumanisation of anyone in society.

The following section discusses the theory underpinning this article, which is decoloniality.

\section{Theoretical Framework: Decoloniality}

The article is couched in decoloniality theory. The theory has roots in Latin America with leading scholars like Walter Mignolo, Maldonado-Torres, Quijon, Dussel (Wanderley and Barros 2018) and championed by Sabelo Gatsheni Ndlovu in South Africa. It was "born out of a realisation that ours is an asymmetrical world order that is sustained not only by colonial matrices of power but also by pedagogies and epistemologies of equilibrium that continue to produce alienated Africans" (Ndlovu-Gatsheni 2013b, p. 11), who, in turn, hate, colonise, and oppress other Africans. In its broader perspective, the theory represents a commitment to challenging and reformulating the communicational scientific discourse, from a criticism of the mediating power of the Eurocentric hegemonic thinking, to a native cultural paradigm (Eliana Herrera and Del Valle Rojas 2016, p. 78). It does so through a deliberate attempt to break with monologic modernity, and issuing an invitation to engage in dialogue (Maldonado-Torres 2011, p. 261). It is, furthermore, a theory that rejects modernity, which is located on the oppressed and exploited side of the colonial difference, in favour of a decolonial liberation struggle to achieve a world beyond Eurocentric ${ }^{1}$ modernity (Grosfoguel 2011, p. 21), dehumanisation, and all acts that seek to reduce people's ontological density. The theory questions the legitimacy and sanity of celebrating postcolonial thinking, while the majority of Africans remain mentally colonised (Kaunda 2015, p. 77). The theory was chosen to inform the thinking of this article since one of the theory's primary mandates is to work towards a vision of human life that is not dependent upon or structured by the forced imposition of one ideal of society on those that differ in ideas (Mignolo 2007). The theory is appropriate in the South African contexts since it engages in a struggle against the Eurocentric design strategy [to colonise African continent], which is visible in religion informed by binarism and hierarchisation, and which keeps power imbalances and the colonial legacy intact (Sithole 2014).

It may be interesting to the reader that, in this article, decoloniality is not used to promote a struggle to decentre the Global North against Global South, as much of decoloniality research does. This article focuses on the Global South versus Global South actors, who, by default or by design, have

1 Eurocentric is a general term used in this paper to refer to what is referred to as West, or Global North, and, more precisely, the African colonisers, whose impact is still felt today, despite 26 years of South African independence. 
replaced Global North colonial masters, and have occupied the big brother mentality of determining what is right and wrong, while at the same time ignoring justice and equity within the prophetic space. To this end, the article agrees with Ndlovu-Gatsheni (2013b, p. 11), who centers around the perspective that the struggle of decoloniality is a "melee against invisible vampirism of imperialism technologies and colonial matrices of power (coloniality) that continue to exist in the minds, lives, languages, dreams, imaginations, and epistemologies of modern subjects in Africa and the entire global South."

As indicated above, the article will consider the three motifs of decoloniality, namely, coloniality of power, knowledge, and critique. The article defines coloniality. Coloniality refers to long-standing patterns of power that emerged as a result of colonialism, but that define culture, labour, intersubjective relations, and knowledge production well beyond the strict limits of colonial administrations. Thus, coloniality survives colonialism (Maldonado-Torres 2011). Coloniality is a name for the 'darker side' of modernity, which needs to be unmasked because it exists as "an embedded logic that enforces control, domination, and exploitation" (Mignolo 1995). Coloniality of power is a useful concept that delves deep into the roots of the present asymmetrical global power relations, and the way the present modern world order was constituted. It boldly enables a correct naming of the current 'global political present,' as a racially hierarchised, Eurocentric, Christian-centric, patriarchal, sexist, capitalist, heteronormative, hegemonic, and modern power structure (Ndlovu-Gatsheni 2013b). Coloniality of power describes modern global power as a network of relations of exploitation, domination, and control of labour, nature and its productive resources, gender and its reproductive species, subjectivity and its material and intersubjective products, and knowledge and authority (Quiano 2007). The coloniality of knowledge poses epistemological questions that are linked to: (a) the politics of knowledge generation; (b) questions of who generates which knowledge and for what purpose; (c) the question of relevance and irrelevance of knowledge; and, (d) how some knowledges disempower/empower communities and peoples (Ake 1982; Ndlovu-Gatsheni 2013a). The article refers to coloniality of knowledge in this article mainly because prophetic movements appear to tussle and compete on issues relating to who has better and more attractive religious knowledge, in order to gain popularity. Coloniality of being is defined by Maldonado-Torres (2011) as the combination of coloniality of power and coloniality of knowledge. Furthermore, coloniality of being is that of racial invention, where the notion of race and nationality is used as the organising principle through combining power and knowledge (Sithole 2014). To this end, there exists the notion that people who are not citizens of a certain country do not belong to its zone of being; thus, they should be subjected to dehumanisation, xenophobia, and other acts that reduce their ontological density. This mentality must be challenged. In essence, the article combines these three motifs, which are pertinent and relevant to the South African context marred with coloniality manifested in many ways, in which one of them is religion.

\section{Factors that Influence Prophetic Conflict in South Africa}

In this section, the article responds to the first question, namely, what are the factors propelling prophetic conflict in South Africa? Responding to this question will expose the readers to the challenge of prophetic conflict in South Africa. In doing so, the article intends to show the need for a Jonathanic theology, which is explained in greater depth when in response to the second question. Various factors are discussed, the first one being popularism.

Prophetic movements in South Africa have been marred by competition, which, in some cases, has gone beyond control, and has led to conflict. Religious adherents or believers move from one prophetic movement to the next, following popular prophets. Arguably, prophetic movements are the fastest growing religious movements in South Africa. While precise statistics are lacking, scholars agree that prosperity gospel followers rival, if not exceed, the numbers of followers of mainstream religions (Van Wyk 2019). This claim implies that some churches or religious groups continue to lose members to big and popular prophetic organisations. Followers of prophetic movements are not captive victims of so-called cult leaders. In fact, they move constantly between churches in search of more 
efficacious "technologies" and "stronger prophets" (Van Wyk 2019). Magezi and Banda (2017) believe that the popularism sought by some contemporary prophets is a sign of them actually competing with Christ-they often project themselves as uniquely anointed by God. There is a silent force among prophets in South Africa, who are on a quest of gaining power through teaching, prophecies, and other actions. Some have required adherents eat snakes, drink diesel, be sprayed with Doom—all to gain power, which, in turn, translates into popularism. The desire for power has forced some prophets to resort to unconventional practices. In some cases, the prophets become, as suggested by Henze (1996, p. 1), legalistic and mind controlling, and they exhibit authoritarian tendencies. Cognisant of these practices, the media, politicians, prophets, and the general populace that were attracted became involved in conflict between those who practice and support what others believe to be malpractices, and those who believe that their mandate is to be harbingers of truth and the pure gospel.

Most foreign prophets have been accused of using faith to extort money from people (CRL Rights Commission 2017). In fact, during hearings of the Commission, some pastors or prophets demonstrated their resistance to the Commission by refusing to take the prescribed oath, refusing to submit the required financial documents and bank statements, and causing dramatic scenes (CRL Rights Commission 2017, p. 17). Some prophets were accused of money laundering, such as Shephard Bushiri (Lindeque 2019; TimesLIVE 2019; Evans 2019), and Pastor Alph Lukau (Montsho 2019; Matangira 2019) - both foreign nationals who operate churches in South Africa. However, according to the CRL Commission report, there are many local religious groups in South Africa who are also deemed to be "profiteering from religion," especially through their refusal to submit their financial records to the CRL commission; these include Pastor Mboro and Prophet Hadebe (CRL Rights Commission 2017). In commenting on prophet Hadebe, Collinson (2017) reports that Hadebe refused to appear before the Commission and ignored its request to view his church's financial statements.

Shepherd Bushiri, a well-known leader who had been accused of prophetpreneurship, is a Malawian who was arrested in 2018 on allegations of fraud and money laundering, among other crimes. Bushiri, in response to allegations of commercialising religion, said, "I am a businessman and that is separate from being a prophet. My prosperity is from private businesses. Such questions are not asked from leaders of white churches but when an African man prospers, then it's a problem" (Fihlani 2018).

While the article does not seek to either exonerate or condemn Bushiri, the article submits that, in South Africa, there is the idea that, when one race or nationality does something, like extort believers, it is wrong, and when it is done by another race or nationality, it becomes right. The point, which relates to the source of conflict, is that prophetic movements in South Africa, whether local or foreign, are characterised by commercialisation of religion; however, the outcry becomes louder when the movement involved has foreign origins.

The article has attempted to show that both local and foreign prophets (not only those mentioned) have been accused of profiteering, which, if it is proven to be true, means that prophetic movements must re-examine their relevance in the context of promoting social justice and social transformation. With reference to decoloniality, commercialisation of the gospel is accompanied by power, and this power makes the holder great. I, thus, problematise the commercialisation of the gospel, especially when it is used to subject the poor to even worse poverty, and to dehumanise people through criminal acts that extort money from them. Societies cannot prosper in the context of exploitation, especially by religious leaders, who are supposed to be the moral agents of change. So, in decoloniality, exploitation, whether by local or foreign prophets, must be challenged, and religious misconduct and delinquency must be prosecuted and judged — not based on race, nationality or colour-as these acts remove some people from the zone of being.

In an attempt to gain popularity, prophets have resorted to performing miracles; however, some of these miracles are questionable. One 'miracle' that became problematic was performed by Pastor Alph Lukau, and resulted in an intensification of the call for foreign prophets to return to their own countries and perform miracles for their own people (Matangira 2019; Montsho 2019). A local prophet 
who seemed agitated by this miracle was Prophet Paseka 'Mboro' Motsoeneng, founder of Incredible Happenings Ministries. In responding to Lukau's so-called miracle, Jordaan (2019) cites Mboro saying, "They say I am jealous. What jealous. I gave away cars, houses. There is no competition here. I'm here because the name of Christ has been played with. This miracle is a fraud and if it's not, they must bring proof. Let's talk about it as men of God. That man never died. God will heal people when he wants, in any way he wants. Let's not fake things."

In addition, Lukau's miracle attracted the attention of Bishop Elly Mogodiri of St. Oaks Global Church of Christ, who is cited by Njilo (2019) as commenting that, "I am aware and have been duly advised that this case falls within the ambit of organised crime, fraud and misrepresentation, among other misdemeanours. As a result, I have since approached my local police station, being Hartbeespoort SAPS in the North West province, and opened an organised crime case."

It is clear from this discussion that 'fake miracles' are one of the ways in which prophets gain popularity, and also a source of conflict among the prophetic movements. From a decoloniality lens, this phenomenon refers to coloniality of power, which transfers the prophets who are deemed powerful to the zone of special being, while those prophets who cannot perform such miracles are moved from the zone of being. Decoloniality evokes the need to challenge acts and narratives that enhance people's ontological density at the expense of made-up miracles.

Criminality or mafia-based tendencies that are hidden in religious narratives are one of the common issues that haunt the prophetic movement in South Africa, and serve as a cause of conflict. Kgatle (2017) describes criminal or mafia groups as "churches [that] are known for their refusal to affiliate with established denominations in South Africa. Some of these churches also refuse to be part of the South African Council of Churches (SACC)." In most cases, these mafia churches strive, as suggested by Damiani (2002, p. 45), by "destroying any individual personality and replace the void with a cultic personality that no longer questions, thinks critically, or feels the impact of an abusive system." In most cases, this type of criminality is not visible, but is hidden from religious adherents. It causes those who are subjected to it to become incapacitated, and to see, name, describe, and explain it as it is institutionalised, naturalised, and normalised (Sithole 2014). The article agrees with the observation by Magezi and Banda (2017), that, under normal circumstances, prophets are conduits through which God's authority is extended to the believer. Sadly, this creates opportunities for prophets to abuse their followers, because the leaders are feared and considered as beyond questioning (Magezi and Banda 2017).

The list of criminality and mafia tendencies exhibited by both local and foreign prophets is long. For example, Timothy Omotoso is known for rape scandals, money laundering, and human trafficking (Dube et al. 2017); the Seven Angels Ministry for constitutional delinquency, abuse of resources and preventing children from attending school (Dube 2019). In some cases, congregants have to ingest or are sprayed with dangerous poisons, ostensibly as part of a healing process (Jamaica Observer 2016). As long as religious leaders are guilty of such practices, religions will continue to remain a problematic institution in society, and, even worse, create competition which accelerates to conflict. Thus, Kaunda (2015, p. 75) warns that, "as long as African mind remains one of the spaces for oppressive religious structures there seems to be no possibility of academy and knowledge decolonization and consequently, no social transformation, no political progress and no economic development."

In light of these factors, evil or otherwise, the article submits that religious leaders should remain agents for peace, social justice, and accountability, through peaceful resolution of difference, and dialogue as a benchmark that society can follow. The continued conflict, the article submits, is a "darker side" of modernity that needs to be unmasked (Mignolo 2000), because it exists as an embedded logic that enforces control, domination, and exploitation disguised in the language of salvation, progress, and modernisation (Ndlovu-Gatsheni 2013b, p. 13), and protection of citizens from foreign prophets. Cognisant of this, the article suggested the tenets of Jonathanic theology for framing a space for peaceful resolution of the conflict between local and foreign prophets. 


\section{Jonathanic Theology: What Does It Entail and What Opportunities Does It Offer?}

This section responds to the second research question and discusses the themes that have been raised. Jonathanic theology is a term that was coined for the sake of this article, and for future discussions. It should not be confused with the theology propounded by Jonathan Edwards. Rather, it is framed within the story of Jonathan and David (I Samuel 18-20), a biblical passage which intends to evoke a new reading of and thinking on. The article does not intend to use the passage, like many scholars have done, to justify homosexuality or lesbianism, or to read the passage in the context of biblical wars caused by tussles for a throne. There is an attempt to reread the texts anew, informed by Ndlovu-Gatsheni's (2013a) argument that decoloniality emphasises an agenda that involves rethinking the very constitution of the present and the construction and reconstruction of new identities and philosophies. The attempt is to use the text of 1 Samuel 18-20 to tease a new theology of prophetic defence, peace, and peaceful resolution of difference in the context of ambivalence of the prophetic terrain, marked by dislodging prophetic movements with different ideas from one's own. The article wishes to emphasise that prophetic vocation can survive in the contexts of collective effort to defend oppression, racism, and inequality that arise from bolding a different theological stance. The article provides a reread and reinterpreting of 1 Samuel 18-20 informed by a decoloniality lens, especially its motifs of coloniality of power, knowledge, and being. By doing so, the theology embedded within the text will evoke a philosophy of liberation, which entails rehumanisation of the dehumanised, and the courage to care and to love (Mpofu 2017, p. 4).

\subsection{Tenets of the Jonathanic Covenant in 1 Samuel 18-20}

This section unpacks various tenets emanating from the story of David and Jonathan. For the purposes of grounding readers on how the conceptualization of Jonathanic theology came about, the article briefly highlights the story. The story of Jonathan and David is taken from the Bible and, in particular, from 1 Samuel 18-20. Saul was the king of Israel; however, his popularity was diminishing while David was getting a spotlight among the Israelites. Saul was not pleased with David's popularism and sought to kill him. Jonathan was Saul's son and a friend to David. In the context of Saul's attack on David, Jonathan stood to protect David against his father Saul. Jonathan made a covenant with David to ensure that David was protected from Saul and, likewise, David was to remember the family of Jonathan when he ascended to the throne, which he did with Mephibosheth in 2 Samuel 9. The bottom line of the story is a commitment of Jonathan to promote peace in the context of political and religious contexts, which made me reread the story and see its applicability in the prophetic movements in South Africa, to tease new meanings of the story and debates in the field of religion, politics, and peace towards contributing to a better future for all.

While Jonathan and David were not prophets, the principles within the story can be applied into the South African prophetic space. Referring to it as Jonathanic theology does not seek to undermine the role played by David in this story, it is not the case; the article refers to Jonathanic theology because it was Jonathan who took the initiative to protect, defend, and make peace with David in the face of Saul's brutality towards David. Jonathan's actions can make up a theology on its own, especially with reference to his defence of David, and his attempts to make peace with David, regardless of Jonathan being a potential heir to the throne should David be deposed. The approach is relevant and serves as a reminder, as postulated by Abbink (2014, p. 89), that religious leaders are not only community leaders and preachers, but also moral authorities who play mediating roles in solving local conflicts-also between people of different faiths or denominations-and they should not be promoting violence and hatred of people of difference. To this end, the article identified four tenets that define Jonathanic theology for peaceful resolution of difference, namely, brotherly love greater than the throne, defence for the afflicted in society, sincerity to power, and commitment to purpose. Below, informed by decoloniality motifs, these tenets will be discussed in detail. 


\subsubsection{Brotherly Love Greater Than the Throne}

According to the Israelite tradition, it was a norm that, after the death of Saul, Jonathan would inherit the throne of his father. However, Jonathan was cognisant of David's capabilities, and that David would be a better king than he would be. Jonathan understood that the throne could be sacrificed for brotherly love.

The articles consider this to be a very important attitude, one that can evoke peace between local and foreign prophetic ministries. Instead of working with people who have ulterior motives, and who are against either local or foreign prophets, we should tap into Jonathan's attitude to handle contemporary issues. Unfortunately, most prophets in South Africa, whether local or foreign, are obsessed by being powerful, popular, and feared, at the expense of cultivating peace in the context of conflict. It should not be understood as saying that it is not ideal or noble for a prophet to be great and influential. However, greatness should not exist at the expense of peace and brotherly love. This attitude is in line with decoloniality thinking, which promotes expansion of people's ontological density that has been shuttered by social injustice, inequality, and hate.

\subsubsection{Defence for the Afflicted in Society}

Faith traditions, from time immemorial, have always dealt with issues affecting the Christian faith privately. The elders took upon themselves the task to protect innocent members of society, while at the same time following a laid-down procedure for disciplining delinquent faith members without attracting public attention - unlike what is currently the way in the South African space. Unfortunately, some prophets, media, and politicians have been used as silencing tools to degrade certain prophets, especially those who are foreign nationals. In essence, the prophetic conflict is often hijacked by politicians and used to push other agendas. To shed light on this, Montsho (2019) cites Wilfrid Napier, a leader of KwaZulu-Natal church leaders, who spoke on behalf of his organisation when he said that, "we are most seriously concerned that some of the political leaders are responsible for this violence by their derogatory and inflammatory statements about migrants, refugees, asylum seekers, and other vulnerable persons." To this end, the article supports Napier's stance; it shows care and the need for justice for everyone, regardless of nationality. The article submits that defending the defenceless, as a core value of a religion such as Christianity, is a viable way to end conflict.

While the media and the public have the right to express anger about foreign prophets who have mafia tendencies, it only becomes, unfortunately, when prophets, without following a biblical procedure given in 1 Corinthians 6 , team up with the media and the public to displace prophets of difference.

Rereading the Jonathan and David narratives paints a new picture of how leaders must behave when they face conflict. When it became clear to Jonathan that David was hated for being popular, Jonathan did not join forces with his father to destroy David, but instead, defended David with all his might. To Jonathan, defending the less privileged in society is a faith mandate, which must be pursued by all in society who love peace, justice, and fairness. Prophets should lead by example in this regard. This approach to resolving conflict supports decoloniality thinking, since this approach helps a new and better life to be reimagined for all and brings dehumanised people back to the zone of being.

\subsubsection{Speaking Truth to Power}

The concept of speaking truth to power can be traced to the works of Quakers and Gandhian ethics (Dordfarm 2013; Merryn 2008). It was a nonviolent approach to resolving conflict (Szenkovics 2013). The concept is borrowed in this article to evoke the need of peace and it relates well with the story of David and Jonathan. Peace begins with truth and, without truth, meaningful peace cannot be achieved. The article is aware that the word sincerity is relative and problematic, especially within postmodern and neoliberal thinking. Therefore, the desire is that sincerity is understood as collective engagement and dialogue, which challenges mafia and criminal tendencies in religious organisations in South 
Africa. It is unfortunate that many popular prophets in South Africa are, by nature, untouchable; they cannot be called to accountability, and their ways are the Alpha and Omega of the gospel.

The article problematises this approach to power, because it becomes a source of abuse and a national threat. Decoloniality challenges the coloniality of power that is unquestionable and untouchable, and evokes the need to challenge such practices as a prerequisite for promoting peace and coexistence. Jonathan, in the midst of the conflict between David and Saul, was able to be sincere and challenge Saul's injustice against David. To Jonathan, sincerity was pivotal even though it was not fashionable within his household; thus, through Jonathan's actions, a conclusion can be drawn that sincerity matters even in the context of conflict. Thus, based on the foregoing argument, peace, even in the context of conflict, is important and should be pursued at all costs.

\subsubsection{Commitment to Purpose}

A Jonathanic theology reminds me that, in the context of conflict, prophets, as long called by God, must remain committed to the purpose of their vocation. This commitment involves devoting energy to social transformation, and not in engaging in battles. David, in the context of conflict, remained committed to his purpose and was not distracted to engage in fightbacks with Saul. Jonathanic theology reminds us that greatness cannot be achieved if most of our energy is invested in conflict, instead, we should stay on purpose. Local and foreign prophets can learn much by staying on purpose, despite the pressure and the need for power, and the financial rewards that come with power. Jonathan understood his purpose, even though it meant that David would be greater than he would be; Jonathan was prepared to let go of power and pursue purpose.

The article ends by submitting that peace must be greater than the need for power and knowledge, and embrace a realisation that all people, regardless of nationality, are entitled to live peaceful lives, and that their ontological density must be respected. Through this approach, all humankind can be brought into the zone of being. Religious groups should be harbingers of this noble, desirable, and doable idea of promoting peace. While this may not be an easy task, Desmond Tutu' (2007) encouraged all who sought peace by saying "You dream that yes it is possible for there to be no war any longer. You dream of a world where poverty will be history. You dream of a world where there will be laughter and compassion and caring and gentleness, then continue" not only dreaming but continuing to tease, and challenge structures and narratives that create conflict as opposed to peace as in the scenario discussed in this article

\section{Conclusions}

This article discussed the factors that propel conflict between local and foreign prophets in South Africa. This article highlighted various trajectories that threaten the role of religious leaders as agents that should be promoting peace in society, that religious leaders should be harbingers of social transformation, and that issues such as jealousy, competition, criminality, and mafia tendencies undermine leaders' roles in society. Using three decoloniality motifs, the article problematised the conflict between local and foreign prophets. The tenets of Jonathanic theology were presented, which emanates from the interaction between David and Jonathan during David's conflict with Saul. The article concluded that peace requires effort and that religious leaders, through their practices, narratives, and discourses, must model peace. Even in cases of evident violation of prophetic vocation, procedures that are laid down must be followed without subjecting individuals to dehumanising experiences by dealing with conflict through the media or public embarrassment.

Funding: This research received no external funding.

2 Tutu, Desmond, Mpilo. 2007. Gandhi Lecture on 21 September 2007 at the JMU Convocation Center, Harrisonburg, Virginia. He was introduced by Professor Sushil Mittal, Director of the Mahatma Gandhi Center for Global Nonviolence at James Madison University. 
Conflicts of Interest: The author declares no conflict of interest.

\section{References}

Abbink, Jon. 2014. Religion and politics in Africa: The future of "the secular". Africa Spectrum 49: 83-106. [CrossRef]

Ake, Claude. 1982. Social Science as Imperialism: The Theory of Political Development. Ibadan: Ibadan University Press.

Collinson, Carl. 2017. State Is Trying to Control Religion and Doesn't Listen to Us. Available online: https: //mg.co.za/article/2017-08-30-state-is-trying-to-control-religion-and-doesnt-listen-to-us/ (accessed on 12 October 2019).

CRL Rights Commission. 2017. CRL Rights Commission Report: Commercialisation of Religion E Abuse of People's Belief Systems; Report on the Hearings on the Commercialisation of Religion and Abuse of People's Beliefs Systems. Pretoria: Department of Cooperative Governance and Traditional Affairs.

Damiani, Rich. 2002. Spiritual abuse within the church. its damage and recovery process. Evanel 20: 42-48.

Dordfarm, Ariel. 2013. Speaking Truth to Power. A Toolkit for Action to Create Change in the Classroom and Beyond. New York: Robert F Kennedy Human Rights.

Dube, Bekithemba. 2019. Conundrum of religious mafia and legislation in South Africa: When does religion become a national threat? Reference to the Seven Angels Ministry. Verbum et Ecclesia 40. [CrossRef]

Dube, Bekithemba, Milton Molebatsi Nkoane, and Dipane Hlalele. 2017. The ambivalence of freedom of religion, and unearthing the unlearnt lessons of religious freedom from the Jonestown incident: A decoloniality approach. Journal for the Study of Religion 30: 330-49. [CrossRef]

Evans, Jenni. 2018. Ngcobo Massacre: Mbalula Brands Shoot-Out Church "Satanic". Available online: https://m.news24.com/SouthAfrica/News/ngcobo-massacre-mbalula-brands-shoot-out-churchsatanic-20180224 (accessed on 17 September 2019).

Evans, Sarah. 2019. Sanco: Bushiri Lawyers Xenophobia Accusations an Attempt to Shift the Blame. Available online: https://m.news24.com/SouthAfrica/News/sanco-bushiri-lawyers-xenophobia-accusationsan-attempt-to-shift-the-blame-20190106 (accessed on 22 September 2019).

Fihlani, Pumza. 2018. Meeting the Man Who Says He Can Walk on Air. Available online: https://www.bbc.com/ news/world-africa-43245126 (accessed on 19 October 2019).

Grosfoguel, Ramón. 2011. Decolonizing Post-Colonial Studies and Paradigms of Political-economy: Transmodernity, Decolonial Thinking, and Global Coloniality. Available online: https://escholarship. org/uc/item/21k6t3fq (accessed on 11 August 2019).

Henze, Donald. 1996. Spiritual Abuse. London: Watchman Fellowship International.

Eliana Herrera, Francisco Sierra Caballero, and Carlos Del Valle Rojas. 2016. Towards an Epistemology of the South . Decoloniality, Informative Knowledge Power and the New Latin-American Community. Chasqui: Latioamericana de Comunicacion.

Jamaica Observer. 2016. South African Prophet Sprays Followers with Insect Killer. Available online: http: //www.jamaicaobserver.com/news/South-African--prophet--sprays-followers-with-insect-killer (accessed on 22 October 2019).

Jordaan, Nomahlubi. 2019. Let's Not Fake Things, Pastor Mboro Implores Pastor Alph Lukau. Available online: https://www.sowetanlive.co.za/news/south-africa/2019-02-28-lets-not-fake-things-pastor-mboroimplores-pastor-alph-lukau/ (accessed on 10 September 2019).

Kaunda, Chammah. 2015. The denial of African agency: A decolonial theological turn. Black Theology 13: 73-92. [CrossRef]

Kgatle, Mookgo S. 2017. The unusual practices within some neo-pentecostal churches in South Africa: Reflections and recommendations. HTS Teologiese Studies/Theological Studies 73: 8. [CrossRef]

Kgatle, Mookgo S. 2018. The prophetic voice of the South African Council of Churches: A weak voice in post-1994 South Africa. HTS Teologiese Studies/Theological Studies 74: 8. [CrossRef]

Lindeque, Mia. 2019. Bushiri \& Wife Back in Court for Money Laundering Trial. Available online: https://ewn.co. za/2019/08/29/bushiri-and-wife-back-in-court-for-money-laundering-trial (accessed on 10 October 2019).

Magezi, Vhumani, and Collium Banda. 2017. Christian ministry and theological education as instruments for economic survival in Africa. HTS Theological Studies/Theological Studies 73: 1-9. [CrossRef] 
Makhudu, Tshegofatso. 2018. Five Religious Scandals That Rocked South Africa. Available online: https: //www.news24.com/SouthAfrica/News/five-religious-scandals-that-rocked-south-africa-20180125 (accessed on 12 September 2019).

Maldonado-Torres, Nelson. 2011. Thinking through the decolonial turn: Post-continental interventions in theory, philosophy, and critique-An Introduction. Transmodernity: Journal of Peripheral Cultural Production of the Luso-Hispanic World 1: 1-15.

Matangira, Lungelo. 2019. It's a Miracle: Cutting Edge Exposes Tricks Used to Con Churchgoers. Available online: https://ewn.co.za/2019/03/13/it-s-a-miracle-show-exposes-tricks-used-to-con-churchgoers (accessed on 12 September 2019).

Merryn, Erin. 2008. Speak Truth to Power. Human Rights Defenders Who Are Changing the World. New York: Robert F Kennedy Human Rights.

Mignolo, Walter D. 1995. The Darker Side of Renaissance. Literacy, territoriality, E Colonization, 2nd ed. University of Michigan Press: Ann Arbor.

Mignolo, Walter. 2000. Local Histories/Global Designs: Coloniality, Subaltern Knowledges, and Border Thinking. Princeton: Princeton University Press.

Mignolo, Walter D. 2007. Delinking: The rhetoric of modernity, the logic of coloniality and the grammar of de-coloniality. Cultural Studies 21: 449-514. [CrossRef]

Montsho, Molaole. 2019. Fraud Charges Laid Against "Resurrection" Pastor Alph Lukau. IOL News. February 26. Available online: https://www.iol.co.za/news/south-africa/north-west/fraud-charges-laidagainst-resurrection-pastor-alph-lukau-19523173 (accessed on 1 August 2019).

Mpofu, William. 2017. Decoloniality as Travelling Theory: Or What Decoloniality Is Not. Available online: https://wiser.wits.ac.za/content/decoloniality-travelling-theory-or-what-decoloniality-not-12918 (accessed on 22 September 2019).

Ndabeni, Khanyi. 2017. Insults, Death Threats for Bling Pastor's Critic. Available online: https://www. timeslive.co.za/sunday-times/news/2017-01-15-insults-death-threats-for-bling-pastors-critic/ (accessed on 15 October 2019).

Ndlovu-Gatsheni, Sabelo J. 2013a. Empire, Global Coloniality and African Subjectivity; New York: Berghahn Books, 1st ed. Available online: https://www.jstor.org/stable/j.ctt9qcvmf (accessed on 17 October 2019).

Ndlovu-Gatsheni, Sabelo J. 2013b. Why decoloniality in the 21st Century? The Thinker for Thought Leaders 2013: 10-16.

Njilo, Nonkululeko. 2019. Bishop Slams 'Pulpit Greed', Opens Criminal Case against Pastor Lukau. SowetanLIVE. February 26. Available online: https://www.sowetanlive.co.za/news/south-africa/2019-02-26-bishop-slamspulpit-greed-opens-criminal-case-against-pastor-lukau/ (accessed on 1 September 2019).

Pondani, Simbarashe. 2019. "Prophets of Doom": The Phenomenon of Healing and Power Dynamics in Neo-Pentecostal African Churches. Master's thesis, Stellenbosch University, Stellenbosch, South Africa. Available online: https://scholar.sun.ac.za:443/handle/10019.1/106082 (accessed on 12 September 2019).

Quiano, Aníbal. 2007. Coloniality and modernity or rationality. Cultural Studies 21: 168-78. [CrossRef]

Sain, Rashil. 2018. Petition Calls for Shutdown of Foreign Prophetic Churches in SA. Pretoria News. October 23. Available online: https:/www.iol.co.za/pretoria-news/petition-calls-for-shutdown-of-foreign-propheticchurches-in-sa-17597255 (accessed on 18 August 2019).

Sithole, Tendayi. 2014. Achille Mbembe: Subject, Subjection, and Subjectivity. Ph.D. thesis, University of South Africa, Pretoria, South Africa. Available online: http://uir.unisa.ac.za/bitstream/handle/10500/14323/thesis_ sithole_t.pdf?sequence=1 (accessed on 17 September 2019).

Sun Reporter. 2019. Angry Residents Gather to Burn Bushiri's Church'. Daily Sun. January 5. Available online: https:/www.dailysun.co.za/News/National/angry-residents-gather-to-burn-bushirischurch-20190105 (accessed on 19 October 2019).

Szenkovics, Dezso. 2013. The Relevance of Mahatma Gandhi's Philosophy for the 21st Century. Acta Universitatis Sapientiae, European and Regional Studies 4: 89-99.

TimesLIVE. 2019. Bushiri Money Laundering Case Brought forward Owing to "Security Matters": NPA. TimesLIVE. May 9. Available online: https://www.timeslive.co.za/news/south-africa/2019-05-09-bushirimoney-laundering-case-brought-forward-owing-to-security-matters-npa/ (accessed on 10 October 2019). 
Van Wyk, Ilana. 2019. Why “Money” Gospel Followers Aren't Simply Credulous Dupes. TimesLIVE. February 23. Available online: https://www.timeslive.co.za/news/south-africa/2019-02-23-why-money-gospel-followersarent-simply-credulous-dupes/ (accessed on 11 October 2019).

Vorster, Koos. 2017. Racism in South Africa: Are we at a tipping point? In Togetherness in South Africa. Edited by Jacobus Abraham du Rand, Koos Vorster and Nico Vorster. Cape Town: Aosis Scholarly Books, pp. 59-78. [CrossRef]

Wanderley, Sergio, and Amos Barros. 2018. Decoloniality, geopolitics of knowledge and historic turn: Towards a Latin American agenda. Management and Organisational History 14: 79-97. [CrossRef]

C 2020 by the author. Licensee MDPI, Basel, Switzerland. This article is an open access article distributed under the terms and conditions of the Creative Commons Attribution (CC BY) license (http://creativecommons.org/licenses/by/4.0/). 